Vol. 13(28), pp. 2819-2829, 9 J uly, 2014

DOI: 10.5897/AJ B2014.13792

Article Number. DF4F43845880

ISSN 1684-5315

Copyright (c) 2014

African Journal of Biotechnology

Author(s) reta in the copyright of this artic le

http://www.academicjoumals.org/A/B

\title{
Can hydrogen peroxide and quercetin improve production of Eucalyptus grandis x Eucalyptus urophylla?
}

\author{
Débora Zanoni do Prado $^{1}$, Roberta Carvalho Dionizio ${ }^{1}$, Fabio Vianello ${ }^{2}$, Massimiliano Magro ${ }^{2}$ \\ and Giuseppina Pace Pereira Lima ${ }^{1 *}$
}

${ }^{1}$ Department of Chemistry and Biochemistry, Universidade Estadual Paulista (UNESP), Botucatu, Brazil.
2 Department of Comparative Biomedicine and Food Science, University of Padua (UNIPD), Padua, Italy.

Received 13 March, 2014; Accepted 16 June, 2014

\begin{abstract}
Vegetative propagation is considered the best choice for the rapid multiplication of plant species, however, rooting may still present difficulties. Substances, such as auxins, phenolic compounds and hydrogen peroxide, are recognized as able to improve this process. The aim of the present work was to determine if hydrogen peroxide in combination with quercetin or indole butyric acid, can modify some characteristics related to rooting and development in cuttings of Eucalyptus grandis x Eucalyptus urophylla. Cuttings were periodically evaluated at 30,60 and 90 days according to the following criteria: height, diameter and survival percentage. After planting (90 days), a destructive evaluation was performed to determine rooting percentage, average size and number of roots. Polyamines content and polyamine oxidase activity, as biochemical markers of plant development, were determined. No statistically significant differences in height, diameter, survival and rooting percentage, root length and number of roots per cuttings were found. Treatments induced a decrease in putrescine levels and polyamine oxidase activity in roots. For absence of positive responses, the use of these substances as a treatment to improve cutting production is economically unviable.
\end{abstract}

Key words: Phenolic compounds, indole butyric acid, vegetative propagation, cuttings.

\section{INTRODUCTION}

Vegetative propagation is considered an ideal choice for the rapid multiplication of species, which maintain desirable characteristics. However, rooting of tree species by cuttings may be hampered by several factors, such as the cutting position, the age of the donor plant and possible treatments with indole butyric acid (IBA) (Hartmann et al., 2002).
Hormones and plant growth regulators, such as synthetic auxins (IBA) play complex roles on rooting and can have direct (cell growth or division) and indirect (interacting with other molecules or plant hormones) effects (Corrêa and Fett-Neto, 2004).

Some substances, such as phenolic compounds and

${ }^{*}$ Corresponding author. E-mail: gpplima@ibb.unesp.br

Author(s) agree that this article remain permanently open access under the terms of the Creative Commons Attribution License 4.0 International License 
hydrogen peroxide has been identified as important regulators of auxin production in plants. Some phenolic groups, such as p-diphenols, o-diphenols, polyphenols, coumarins and flavonoids, namely quercetin, are described as inhibitors of indoleacedic acid (IAA) oxidation (Banduski et al., 1995) by inhibition of IAA oxidase (Pandey and Pathak, 1981).

The accumulation of $\mathrm{H}_{2} \mathrm{O}_{2}$ during root formation and its beneficial effects, at low concentrations, has been pointed out in several studies (Dunand et al., 2007; Li et al., 2009). Improvements in rooting were described when this substance was associated with auxins (Sebastiani and Tognetti, 2004; Franklin and Dias, 2011).

PAs play critical roles in a variety of physiological and developmental processes, such as regulation of cell proliferation, somatic embryogenesis, differentiation and morphogenesis (Kusano et al., 2008). Relationships between polyamines and different aspects of root development, such as increases in meristematic activity, elongation, lateral and adventitious roots formation have been discussed in several studies (Couée et al., 2004). The addition of PAs significantly improved root formation and/or growth in sweet orange, depending on their concentration, whereas the presence of inhibitor of PAs biosynthesis, such as a-difluoromethylornithine (DFMO), inhibited these processes (Mendes et al., 2011). Agmatine (Agm), spermidine (Spd) and spermine (Spm) levels were positively related to root development, while the content of putrescine (Put) has neutral or negative effect (Su et al., 2006). Moreover, PAs are known to play a role against oxidative damage. This antioxidant effect is probably due to the combination of their free radical scavenging properties inhibiting lipid peroxidation reactions catalyzed by metals, and the production of hydrogen peroxide by the action of amine oxidases (Groppa and Benavides, 2008). Polyamine oxidases (PAOs) (EC 1.5.3.11) are responsible for catalyzing the oxidation of polyamines, such as spermine (Spm) and spermidine (Spd), and/or of their acetylated derivatives (Angelini et al., 2010). These enzymes present a direct relationship with auxin content in plants. The application of exogenous auxin can induce an increased expression of PAOs during growth of corn mesocotyls (Cona et al., 2003). In a previous study, it was demonstrated that the enzymes polyamine oxidase and diamine oxidase (DAO/PAO) are inversely related to endogenous polyamines levels in the rooting induction phase. Hydrogen peroxide levels were positively related to DAO and PAO activity, as one of the final products of polyamines oxidation (Nag et al., 2001).

The great interest in the improvement of the quality of Eucalyptus seedlings and the good results obtained in previous studies on rooting, led us to the present experimental work aimed at evaluating the levels of polyamines on the basis of the effect of hydrogen peroxide responses, the flavonoid quercetin, and indole butyric acid during the rooting and development of cuttings of $E$. grandis $x$ E. urophylla.

\section{MATERIALS AND METHODS}

Cuttings of E. grandis $x$ E. urophylla, clone (CL1), from Duratex S.A. (Sao Paulo, Brazil) were used for the experiments, which were carried out at the Central Nursery farm of Duratex corporation, located in the municipality of Lençóis Paulista, Sao Paulo, Brazil, at $22^{\circ} 35^{\prime} 55^{\prime \prime}$ South latitude and $48^{\circ} 48^{\prime} 01^{\prime \prime}$ West longitude, $560 \mathrm{~m}$ altitude, in the Midwest region of the Sao Paulo state. The region present an Aw (tropical) climate, according to the Köppen classification, with $1133 \mathrm{~mm}$ annual average rainfall, $23.3^{\circ} \mathrm{C}$ mean annual temperature, with 29.1 and $17.6^{\circ} \mathrm{C}$ as maximum and minimum values, respectively.

\section{Cuttings collection}

The collection of cuttings, 3-6 cm long, was accomplished at Duratex S.A.in cement channels, $90 \mathrm{~cm}$ wide. Cuttings were picked up from $20 \mathrm{~cm}$ strains. Scissors were sterilized with $70 \%$ alcohol to prevent contamination by pathogens and a cooler, in which the cuttings were placed and used for data collection. The cuttings were sprayed with calcium plus boron $(\mathrm{Ca}+\mathrm{B})$, at $15 \pm 5^{\circ} \mathrm{C}$, every $10 \mathrm{~min}$, to maintain the redox conditions of swelling solution. Cuttings, obtained from $E$. urophylla $x$ grandis clones (CL1), were standardized in sizes from 3 to $6 \mathrm{~cm}$ long and 1.5 to $2.5 \mathrm{~mm}$ in diameter. Stakes were free of pathogens and presented one to three leaf pairs. Half of leaf area was removed to decrease excess sweating and water loss. The period spent under cutting collecting was always lower than 30 min to minimize cutting loss by oxidation.

\section{Tillage treatments}

Treatment solutions, in which cuttings were dipped, were freshly prepared. In this study three experiments were performed. In the first experiment, due to the low solubility in water, $98 \%$ quercetin (Sigma, Brazil) and indole butyric acid (IBA) 98\% (Sigma, Brazil) were dissolved in acetone, and then mixed with $\mathrm{CaSO}_{4}$ in different combinations for following treatments: T1- control; T2 - quercetin $\left(0.25 \mathrm{~g} \mathrm{~kg}^{-1}\right)$; T3 - quercetin $\left(0.5 \mathrm{~g} \mathrm{~kg}^{-1}\right)$; T4 - quercetin $\left(1.0 \mathrm{~g} \mathrm{~kg}^{-1}\right)$; T5 - IBA (1.0 g kg-1); T6 - IBA $\left(1.0 \mathrm{~g} \mathrm{~kg}^{-1}\right)+$ quercetin $\left(0.25 \mathrm{~g} \mathrm{~kg}^{-1}\right)$; T7 - IBA $\left(1.0 \mathrm{~g} \mathrm{~kg}^{-1}\right)+$ quercetin $\left(0.5 \mathrm{~g} \mathrm{~kg}^{-1}\right)$; T8 - IBA $\left(1.0 \mathrm{~g} \mathrm{~kg}^{-1}\right)+$ quercetin $\left(1.0 \mathrm{~g} \mathrm{~kg}^{-1}\right)$.

For the peroxide second experiment, $30 \%$ hydrogen peroxide (Merck, Brazil) (v/v) and IBA, mixed with $\mathrm{CaSO}_{4}$ in the following combinations, were used: T1 - control; T2 - hydrogen peroxide (1.75\%); T3 - hydrogen (3.5\%); T4 - hydrogen peroxide (7.0\%); T5 IBA $\left(1.0 \mathrm{~g} \mathrm{~kg}^{-1}\right)$; T6 - IBA $\left(1.0 \mathrm{~g} \mathrm{~kg}^{-1}\right)+$ hydrogen peroxide $(1.75 \%)$; T7 - IBA $\left(1.0 \mathrm{~g} \mathrm{~kg}^{-1}\right)+$ hydrogen peroxide $(3.5 \%)$; T8 - IBA $(1.0 \mathrm{~g} \mathrm{~kg}$ $\left.{ }^{1}\right)+$ hydrogen peroxide $(7.0 \%)$.

The third experiment was carried out by combining the most appropriate treatment with hydrogen peroxide and quercetin, from previous experiments, and associated with IBA, according to the following combinations: T1 - control; T2 - quercetin $\left(0.5 \mathrm{~g} \mathrm{~kg}^{-1}\right)+$ hydrogen peroxide (3.5\%); T3 - IBA $\left(1.0 \mathrm{~g} \mathrm{~kg}^{-1}\right)$; T4 - quercetin (0.5 $\left.\mathrm{g} \mathrm{kg}^{-1}\right)+$ hydrogen peroxide $(3.5 \%)+$ IBA $\left(1.0 \mathrm{~g} \mathrm{~kg}^{-1}\right)$.

\section{Experimental design}

For the implementation of the first two experiments, a completely randomized design in a $2 \times 4$ factorial arrangement was used, comprising two treatments with auxin, four with hydrogen peroxide and quercetin and 5 replicates with 48 cuttings per experimental unit, totaling 1920 cuttings per test. For the third experiment, a completely randomized in a $2 \times 2$ factorial arrangement was used, with two doses of auxin and two of hydrogen peroxide, combined with quercetin, and five replicates with 48 cuttings per experimental unit, 
totaling 480 cuttings.

\section{Planting of the cuttings}

Cuttings were planted in a substrate composed of Canadian peat, vermiculite and rice hulls, and $4 \mathrm{~kg} \mathrm{~m}^{3}$ single superphosphate fertilizer (SSF, $\mathrm{P}_{2} \mathrm{O}_{5}$ ) and slow release fertilizer, NPK (15/8/12, Basacote ${ }^{\circledR}$ Plus) supplemented with micronutrients, at $1 \mathrm{~kg} \mathrm{~m}^{3}$ in the summer and $3 \mathrm{~kg} \mathrm{~m}^{3}$ in winter. The substrate presented a $\mathrm{C} / \mathrm{N}$ ratio in the $20-45$ range.

Substrate components were blended for $20 \mathrm{~min}$, and then water $\left(20\right.$ to $30 \mathrm{~L}$ ) were added. The substrate was placed in $55 \mathrm{~m}^{3}$ plastic tubes. The bases of the cuttings $(1 \mathrm{~cm})$ were dipped in $\mathrm{CaSO}_{4}$ solutions and then planted. Cuttings were transferred to the greenhouse, where they remained for 23 days at $25-30^{\circ} \mathrm{C}$ and relative humidity above $75 \%$, by nebulizers. Water management was carried out according to the need for irrigation, controlling water saturation of the substrate. There was no need for chemical pest control because of contamination by pathogens was eliminated by the use of carefully controlled materials. After growth in the greenhouse, cuttings were moved to a shade house, where they stayed 20 days for acclimatization. Fertilization composed of macro and micronutrients was applied daily, according to cutting growth and season. After this period, the seedlings were transferred to the full sun area for other 50 days. Then, tray randomization was performed in order to ensure that seedling plants were chosen for independent analysis.

After 15-30 days of growth, a hardening fertilization was performed in which the frequency and volume of irrigation were reduced.

\section{Seedling evaluation}

Among the 48 seedlings comprising each experimental unit, 28 plant seedlings were evaluated. Periodically, at 30,60 and 90 days, seedling height and diameter were measured and survival percentage was evaluated. Then, a destructive evaluation was performed in 20 plants, for the determination of rooting percentage, number of roots per cutting, and the average length of roots, by averaging the longest roots of each repetition.

\section{Determination of polyamines}

Polyamine content was determined according to the method proposed by Flores and Galston (1982), modified by Lima et al. (2008). Briefly, leaves and roots $(0.2 \mathrm{~g})$ were homogenized in $5 \%$ $\mathrm{HClO}_{4}(3 \mathrm{~mL})$. Supernatants $(200 \mu \mathrm{l})$, saturated calcium carbonate $(200 \mu \mathrm{L})$, and dansyl chloride $(400 \mu \mathrm{L})$, were added in test tubes, and left $16 \mathrm{~h}$ in the dark at room temperature. After this period, proline $(100 \mu \mathrm{L})$ was added. Toluene $(500 \mu \mathrm{L})$ was used to extract dansylated polyamines. Toluene soluble extracts were applied to glass plates, coated with $\mathrm{G} 60$ silica gel for thin layer chromategraphy (TLC). For polyamine separation, chloroform-triethylamine $(20: 1, v / v)$ was used as solvent, and the run was monitored by UV light. After approximately $1 \mathrm{~h}$, TLC plates were removed from the solvent solution and dried under air circulation. Polyamines were determined by fluorescence densitometry against standards and results were expressed as mg polyamines (spermidine, spermine and putrescine) $\mathrm{g}^{-1}$ fresh weight.

\section{Determination of polyamine oxidase activity}

Polyamine oxidase activity was determined according to the method reported by Stevanato et al. (1990). Leaves and root samples of E. grandis x E. urophylla (approximately $50 \mathrm{mg}$ ) were assayed in $20 \mathrm{mM}$ Hepes buffer, $\mathrm{pH} 7.0$. The reaction was performed at $30^{\circ} \mathrm{C}$ and followed for $7 \mathrm{~min}$ in a spectrophotometer (Cary 50, Varian, The Netherlands) at $555 \mathrm{~nm}$. The results were expressed in $\Delta$ Abs $\min ^{-1} \mathrm{~g}^{-1}$ fresh matter.

\section{Statistical analysis}

Experimental data were subjected to analysis of variance (ANOVA) and Tukey test $(p<0.05)$.

\section{RESULTS AND DISCUSSION}

\section{Effect of quercetin and IBA on cutting growth}

Data obtained from the destructive evaluation of cuttings, such as rooting, root number and length, did not show statistically significant differences between treatments (Table 1). As well, regarding the effect of quercetin and IBA on plant height, diameter and survival percentage, measured at 30, 60 and 90 days after planting, the $F$ interaction (time $x$ quercetin $x$ IBA) was not significantly different among treatments (Table 2 and Figure 1). For all treatments a high growth in height and diameter, high rooting and survival, including controls (Tables 1 and 2), were observed.

We concluded that other factors, such as environment, genetic material and nutrition and water conditions of donor plants, were the most important influencing factors on seedling development and rooting growth, than the application of auxin and quercetin. Other studies found that rooting can be influenced by injuries, hormonal balance, genetic constitution, presence of inhibitors and nutrition and water conditions of donor plant (Alfenas et al., 2004), and cutting development can be strongly influenced by the maturation/juvenility of seedlings and environmental conditions (Xavier et al., 2009). Conversely, positive results on seedling growth, related to flavonoids and IBA treatment, were observed in other studies. In clones of Eucalyptus benthamii Maiden \& Cambage dunnii Maiden $x$ Eucalyptus, the application of IBA positively influenced the processes of cutting rizogenesis, the rate of root formation and an increase of adventitious rooting (Brondani et al., 2012).

Flavonoids like quercetin, kaempferol, apigenin and other molecules, synthesized in the first process of the flavonoid biosynthetic pathway, demonstrated the ability to inhibit polar auxin transport and thereby increase the accumulation of auxin in plants (Peer and Murphy, 2007). In yerba mate (Ilex paraguariensis), the exogenous application of quercetin resulted in an increase of rooting percentage of 17 to $55 \%$ (Tarragó et al., 2005).

\section{Effect of hydrogen peroxide and IBA on cutting growth and rooting}

No statistically significant differences were observed 
Table 1. Effect of different doses of quercetin $\left(0,0.25,0.5,1.0 \mathrm{~g} \mathrm{~kg}^{-1}\right)$ and indole butyric acid $\left(0,1.0 \mathrm{~g} \mathrm{~kg}^{-1}\right)$ on cutting height and diameter and survival percentage, measured at 30,60 and 90 days after planting of Eucalyptus grandis x Eucalyptus urophylla cuttings.

\begin{tabular}{|c|c|c|c|c|c|c|}
\hline \multirow{3}{*}{ Quercetin } & \multicolumn{2}{|c|}{ Height $(\mathrm{cm})$} & \multicolumn{2}{|c|}{ Diameter (cm) } & \multicolumn{2}{|c|}{ Survival percentage (\%) } \\
\hline & \multicolumn{6}{|c|}{ IBA $\left(\mathrm{g} \mathrm{kg}^{-1}\right)$} \\
\hline & 0 & 1.0 & 0 & 1.0 & $\mathbf{0}$ & 1.0 \\
\hline Quercetin $\left(\mathrm{g} \mathrm{kg}^{-1}\right)$ & \multicolumn{6}{|c|}{30 days } \\
\hline 0 & $7.78 \pm 0.34$ & $7.61 \pm 0.56$ & $1.10 \pm 0.06$ & $1.23 \pm 0.17$ & $89.29 \pm 7.58$ & $90.00 \pm 8.89$ \\
\hline 0.25 & $7.81 \pm 0.59$ & $7.89 \pm 0.19$ & $1.23 \pm 0.17$ & $1.17 \pm 0.08$ & $91.43 \pm 6.96$ & $88.57 \pm 10.53$ \\
\hline 0.5 & $7.83 \pm 0.30$ & $6.99 \pm 0.80$ & $1.21 \pm 0.18$ & $1.15 \pm 0.08$ & $92.86 \pm 6.19$ & $83.57 \pm 8.49$ \\
\hline 1.0 & $7.57 \pm 0.29$ & $7.41 \pm 0.19$ & $1.27 \pm 0.16$ & $1.21 \pm 0.14$ & $93.57 \pm 6.39$ & $95.00 \pm 4.07$ \\
\hline Quercetin $\left(\mathrm{g} \mathrm{kg}^{-1}\right)$ & \multicolumn{6}{|c|}{60 days } \\
\hline 0 & $12.89 \pm 1.04$ & $13.11 \pm 0.95$ & $1.67 \pm 0.16$ & $1.79 \pm 0.06$ & $88.57 \pm 8.89$ & $90.00 \pm 8.89$ \\
\hline 0.25 & $12.34 \pm 1.73$ & $15.15 \pm 1.40$ & $1.69 \pm 0.19$ & $1.82 \pm 0.11$ & $90.71 \pm 5.98$ & $88.57 \pm 10.53$ \\
\hline 0.5 & $13.62 \pm 1.49$ & $13.51 \pm 1.22$ & $1.75 \pm 0.15$ & $1.83 \pm 0.15$ & $92.14 \pm 5.87$ & $83.57 \pm 8.49$ \\
\hline 1.0 & $12.28 \pm 1.43$ & $13.10 \pm 1.75$ & $1.73 \pm 0.15$ & $1.74 \pm 0.11$ & $92.04 \pm 6.02$ & $93.57 \pm 6.87$ \\
\hline Quercetin $\left(\mathrm{g} \mathrm{kg}^{-1}\right)$ & \multicolumn{6}{|c|}{90 days } \\
\hline 0 & $21.87 \pm 1.03$ & $22.55 \pm 0.56$ & $2.14 \pm 0.09$ & $2.25 \pm 0.08$ & $88.57 \pm 8.89$ & $89.29 \pm 8.38$ \\
\hline 0.25 & $21.48 \pm 2.33$ & $24.05 \pm 1.27$ & $2.12 \pm 0.14$ & $2.35 \pm 0.15$ & $90.71 \pm 5.98$ & $88.57 \pm 10.53$ \\
\hline 0.5 & $23.65 \pm 2.18$ & $22.70 \pm 0.43$ & $2.23 \pm 0.09$ & $2.26 \pm 0.08$ & $92.14 \pm 5.87$ & $83.57 \pm 8.49$ \\
\hline 1.0 & $21.60 \pm 2.32$ & $22.50 \pm 2.97$ & $2.15 \pm 0.15$ & $2.26 \pm 0.14$ & $91.43 \pm 5.42$ & $93.57 \pm 6.87$ \\
\hline $\mathrm{F}$ & & 0.20 & & 0.10 & & 0.83 \\
\hline
\end{tabular}

Table 2. Effect of hydrogen peroxide $(0,1.75,3.5,7.0 \%, \mathrm{v} / \mathrm{v})$ and indole butyric acid $\left(0,1.0 \mathrm{~g} \mathrm{~kg}^{-1}\right)$ on height $(\mathrm{cm})$, diameter $(\mathrm{cm})$ and survival percentage, of Eucalyptus grandis x Eucalyptus urophylla cuttings, measured at 30,60 and 90 days after planting.

\begin{tabular}{|c|c|c|c|c|c|c|}
\hline \multirow{3}{*}{$\begin{array}{l}\text { Hydrogen } \\
\text { peroxide }\end{array}$} & \multicolumn{2}{|c|}{ Height (cm) } & \multirow{2}{*}{\multicolumn{2}{|c|}{$\begin{array}{c}\text { Diameter }(\mathrm{cm}) \\
\text { IBA }\left(\mathrm{g} \mathrm{kg}^{-1}\right)\end{array}$}} & \multicolumn{2}{|c|}{ Survival percentage (\%) } \\
\hline & & & & & & \\
\hline & 0 & 1.0 & 0 & 1.0 & 0 & 1.0 \\
\hline 0 & $7.18 \pm 0.37$ & $7.71 \pm 0.40$ & $1.16 \pm 0.04$ & $1.22 \pm 0.07$ & $92.86 \pm 8.38$ & $93.57 \pm 7.74$ \\
\hline 1.75 & $8.03 \pm 0.55$ & $8.06 \pm 0.77$ & $1.28 \pm 0.20$ & $1.33 \pm 0.22$ & $95.00 \pm 7.41$ & $95.00 \pm 5.42$ \\
\hline $\mathrm{H}_{2} \mathrm{O}_{2}(\%)$ & \multicolumn{6}{|c|}{60 days } \\
\hline 0 & $13.93 \pm 1.58$ & $14.73 \pm 1.14$ & $1.76 \pm 0.14$ & $1.84 \pm 0.07$ & $92.86 \pm 8.38$ & $93.57 \pm 7.74$ \\
\hline 1.75 & $15.19 \pm 2.03$ & $14.60 \pm 0.94$ & $1.86 \pm 0.10$ & $1.84 \pm 0.11$ & $95.00 \pm 7.41$ & $95.00 \pm 5.42$ \\
\hline 3.5 & $14.09 \pm 1.48$ & $14.88 \pm 1.63$ & $1.81 \pm 0.09$ & $1.89 \pm 0.10$ & $95.71 \pm 2.99$ & $93.57 \pm 3.91$ \\
\hline 1.75 & $25.52 \pm 3.04$ & $25.38 \pm 1.08$ & $2.33 \pm 0.17$ & $2.25 \pm 0.13$ & $95.00 \pm 7.41$ & $93.57 \pm 6.87$ \\
\hline 3.5 & $23.72 \pm 1.78$ & $25.95 \pm 1.60$ & $2.17 \pm 0.13$ & $2.29 \pm 0.13$ & $95.71 \pm 2.99$ & $90.71 \pm 6.96$ \\
\hline 7 & $24.89 \pm 1.54$ & $26.22 \pm 1.04$ & $2.22 \pm 0.15$ & $2.25 \pm 0.06$ & $93.57 \pm 6.39$ & $92.86 \pm 6.96$ \\
\hline $\mathrm{F}$ & \multicolumn{2}{|c|}{0.90} & & 0.49 & & 0.88 \\
\hline
\end{tabular}

among treatments for the measured parameters, from the destructive evaluation of samples, such as rooting, root number and length (Table 3). Regarding treatments with $\mathrm{H}_{2} \mathrm{O}_{2}$ and IBA on periodically measured parameters, cutting height, diameter and percentage of survival, the $\mathrm{F}$ interaction (time $\mathrm{x}$ hydrogen peroxide $\mathrm{x}$ auxin) were, as well, not significantly different among treatments (Table 4). 

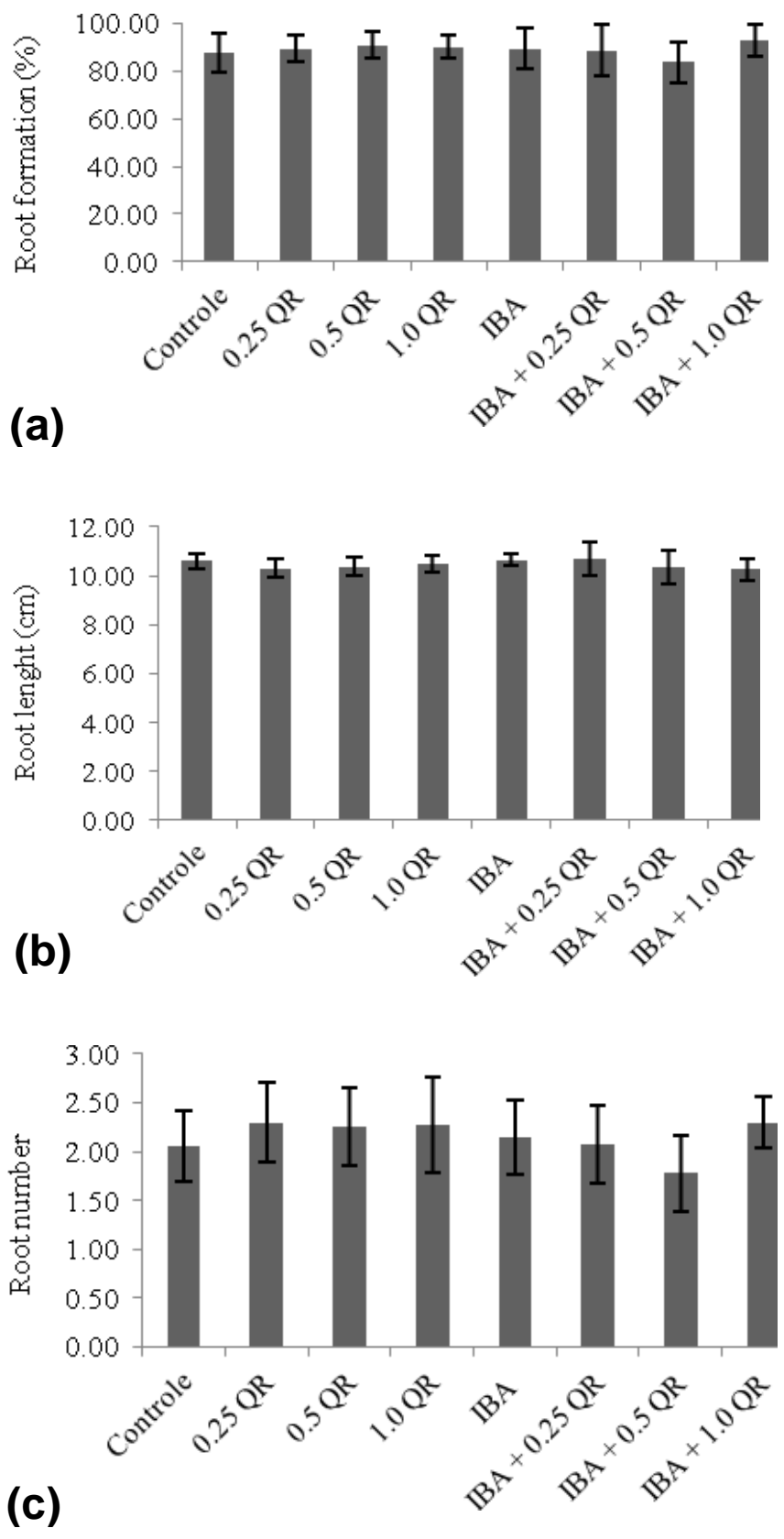

Figure 1. Effect of different doses of quercetin $(0,0.25,0.5,1.0$ $\left.\mathrm{g} \mathrm{kg}^{-1}\right)$ and indole butyric acid $\left(0,1.0 \mathrm{~g} \mathrm{~kg}^{-1}\right)$ on (a) rooting percentage (\%), (b) root length $(\mathrm{cm})$ and (c) root number, measured at 90 days after planting of Eucalyptus grandis $\mathrm{x}$ Eucalyptus urophylla cuttings.

In the evaluation of E. grandis $x$ E. urophylla samples, for all treatments, all measured parameters showed satisfactory results, including controls, and we may infer that other factors, such as environmental conditions, genetic features, and care in cutting handling were decisive for seedling development. Some authors claimed that the presence of hydrogen peroxide can affect the growth and differentiation of roots (Dunand et al., 2007; Sebastiani and Tognetti, 2004). In olive cuttings (Olea europaea L.), at the end of the rooting period ( $88^{\text {th }}$ day), roots number increased by $3.5 \%$ with $\mathrm{H}_{2} \mathrm{O}_{2}$ treatment in comparison to IBA treatment alone (3.40 versus 1.95 roots per cutting at $4.0 \mathrm{~g} \mathrm{~kg}^{-1}$ IBA and 1.80 versus 1.08 roots per cutting at $2.0 \mathrm{~g} \mathrm{~kg}^{-1}$ IBA) (Sebastiani et al., 2002). However, our results showed no changes in rooting according to the levels of peroxide. Probably, other factors, such as genetic and environmental conditions may influence the development of $E$. grandis $x$ urophylla samples, and no appa- 
Table 3. Effect of the addition of quercetin $\left(0.5 \mathrm{~g} \mathrm{~kg}^{-1}\right)$, associated with hydrogen peroxide (3.5 \%), and indole butyric acid (1.0 g kg $\left.{ }^{-1}\right)$ on seedling height $(\mathrm{cm})$, diameter $(\mathrm{cm})$ and survival percentage, measured at 30,60 and 90 days after planting of Eucalyptus grandis $\mathrm{x}$ Eucalyptus urophylla cuttings.

\begin{tabular}{|c|c|c|c|c|c|c|}
\hline \multirow{3}{*}{$\begin{array}{l}\text { Quercetin + hydrogen } \\
\text { peroxide }\end{array}$} & \multicolumn{2}{|c|}{ Height $(\mathrm{cm})$} & \multicolumn{2}{|c|}{ Diameter (cm) } & \multicolumn{2}{|c|}{ Survival (\%) } \\
\hline & \multicolumn{6}{|c|}{ IBA $\left(\mathrm{gkg}^{-1}\right)$} \\
\hline & 0 & 1.0 & 0 & 1.0 & 0 & 1.0 \\
\hline Quercetin $\left(\mathrm{g} \mathrm{kg}^{-1}\right)+\mathrm{H}_{2} \mathrm{O}_{2}(\%)$ & \multicolumn{6}{|c|}{30 days } \\
\hline $0.0+0.0$ & $7.09 \pm 0.39$ & $7.15 \pm 0.36$ & $0.83 \pm 0.12$ & $0.85 \pm 0.07$ & $90.71 \pm 4.07$ & $90.71 \pm 5.42$ \\
\hline $0.5+3.5$ & $7.60 \pm 0.52$ & $7.03 \pm 0.41$ & $0.87 \pm 0.07$ & $0.84 \pm 0.07$ & $85.71 \pm 4.37$ & $90.00 \pm 8.89$ \\
\hline Quercetin $\left(\mathrm{g} \mathrm{kg}^{-1}\right)+\mathrm{H}_{2} \mathrm{O}_{2}(\%)$ & \multicolumn{6}{|c|}{60 days } \\
\hline $0.0+0.0$ & $11.59 \pm 0.73$ & $11.97 \pm 1.32$ & $1.62 \pm 0.06$ & $1.71 \pm 0.07$ & $76.43 \pm 11.18$ & $75.71 \pm 7.32$ \\
\hline $0.5+3.5$ & $12.63 \pm 1.57$ & $11.99 \pm 0.77$ & $1.62 \pm 0.18$ & $1.64 \pm 0.09$ & $72.86 \pm 7.41$ & $72.14 \pm 5.30$ \\
\hline Quercetina $\left(\mathrm{g} \mathrm{kg}^{-1}\right)+\mathrm{H}_{2} \mathrm{O}_{2}(\%)$ & \multicolumn{6}{|c|}{90 days } \\
\hline $0.0+0.0$ & $16.28 \pm 0.78$ & $16.84 \pm 1.81$ & $1.94 \pm 0.13$ & $2.04 \pm 0.13$ & $71.43 \pm 7.58$ & $71.43 \pm 6.68$ \\
\hline $0.5+3.5$ & $18.15 \pm 2.35$ & $17.05 \pm 0.71$ & $2.13 \pm 0.18$ & $2.01 \pm 0.12$ & $72.14 \pm 9.24$ & $70.00 \pm 6.49$ \\
\hline $\mathrm{F}$ & \multicolumn{2}{|c|}{0.59} & & 0.28 & \multicolumn{2}{|c|}{0.78} \\
\hline
\end{tabular}

Table 4. Content of polyamines (putrescine, spermidine and spermine, expressed in $\mu \mathrm{g} \mathrm{g}^{-1}$ fresh tissue) in leaves and roots of Eucalyptus grandis $x$ Eucalyptus urophylla seedlings treated with different combinations of hydrogen peroxide (3.5 \%), quercetin (0.5 $\left.\mathrm{g} \mathrm{kg}^{-1}\right)$ and indole butyric acid $\left(1.0 \mathrm{~g} \mathrm{~kg}^{-1}\right)$.

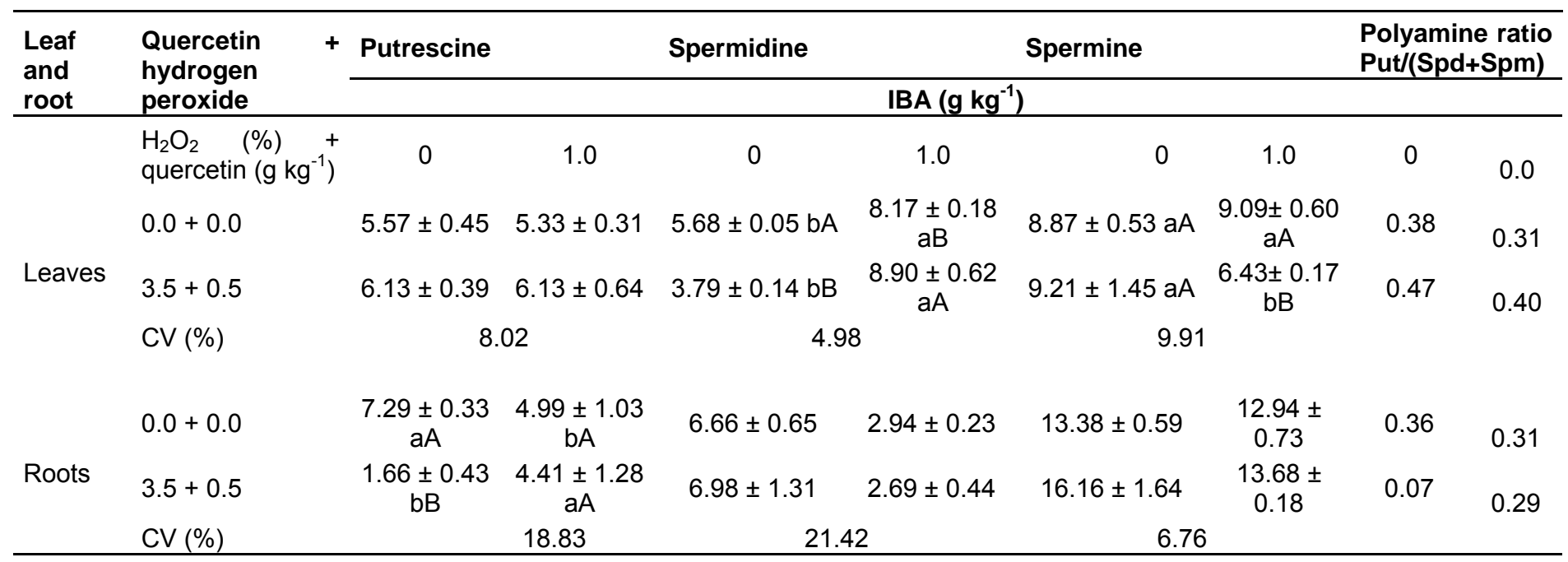

*Lowercase letters compare means between treatments with indole butyric acid. Capital letters compare levels of hydrogen peroxide between each concentration of auxin. Means followed by the same letter are not statistically different by the Tukey test at $5 \%$ probability

rent effect was noticed with the applied substances (Figure 2).

\section{Effect of quercetin, hydrogen peroxide and IBA on development of Eucalyptus cuttings}

An important reduction of the percentage of survival at 30 and 60 days after planting was observed (Table 2), which was attributed to the moving of seedlings from the shaded house to the full sun for hardening and acclimatization, occurring in May, characterized by the reduction of daily light and temperature, which hindered the establishment of seedlings. At the same time a low development of seedling height, diameter, root length and number was observed, when compared to previous experiments. This effect could be attributed to the different period during the year: the first two experiments were carried out from October to the end of December, while the second experiment was performed in March, ending in May. The last one has fewer daily light hours, and lower temperature and rainfall, which may have hampered the development of the seedlings. Despite these lower 

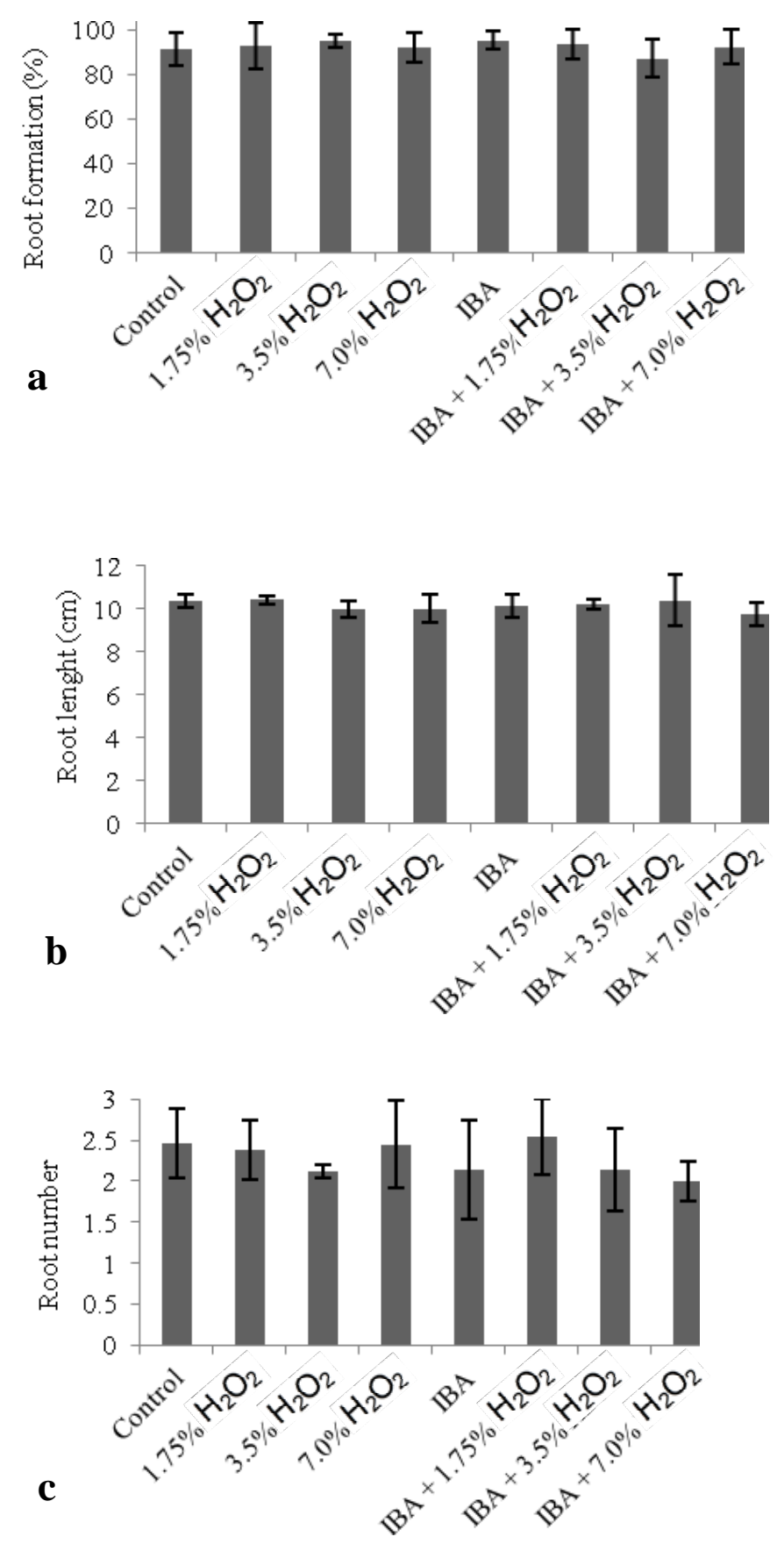

Figure 2. Effect of hydrogen peroxide $(0,1.75,3.5,7.0 \%, \mathrm{v} / \mathrm{v})$ and indole butyric acid $\left(0,1.0 \mathrm{~g} \mathrm{~kg}^{-1}\right)$ on (a) root formation (\%), (b) root length $(\mathrm{cm})$ and (c) root number, measured at 90 days after planting of Eucalyptus grandis x Eucalyptus urophylla cuttings.

results, biometric variables during experiments showed a good performance, which emphasizes the influence of genetic factor for successful planting. The doses of auxin and quercetin, associated with hydrogen peroxide, and their combinations, showed no influence on sample development. In other studies, positive results were found. An effect of IBA on rooting of hardwood cuttings of several species, such as fig (Ficus carica) (Pio et al., 2003) and blueberry (Vaccinium ashei) (Vignolo et al., 2012) has been reported. The application of quercetin increased rooting rate of 17 to $55 \%$ in yerba mate (Tarrago et al., 2005). Hydrogen peroxide has also been described as effective in root forming in cuttings of olive (Olea europaea L.), favoring both the formation of roots and increasing the number of roots per cutting (Sebastiani and Tognetti, 2004) (Figure 3). 

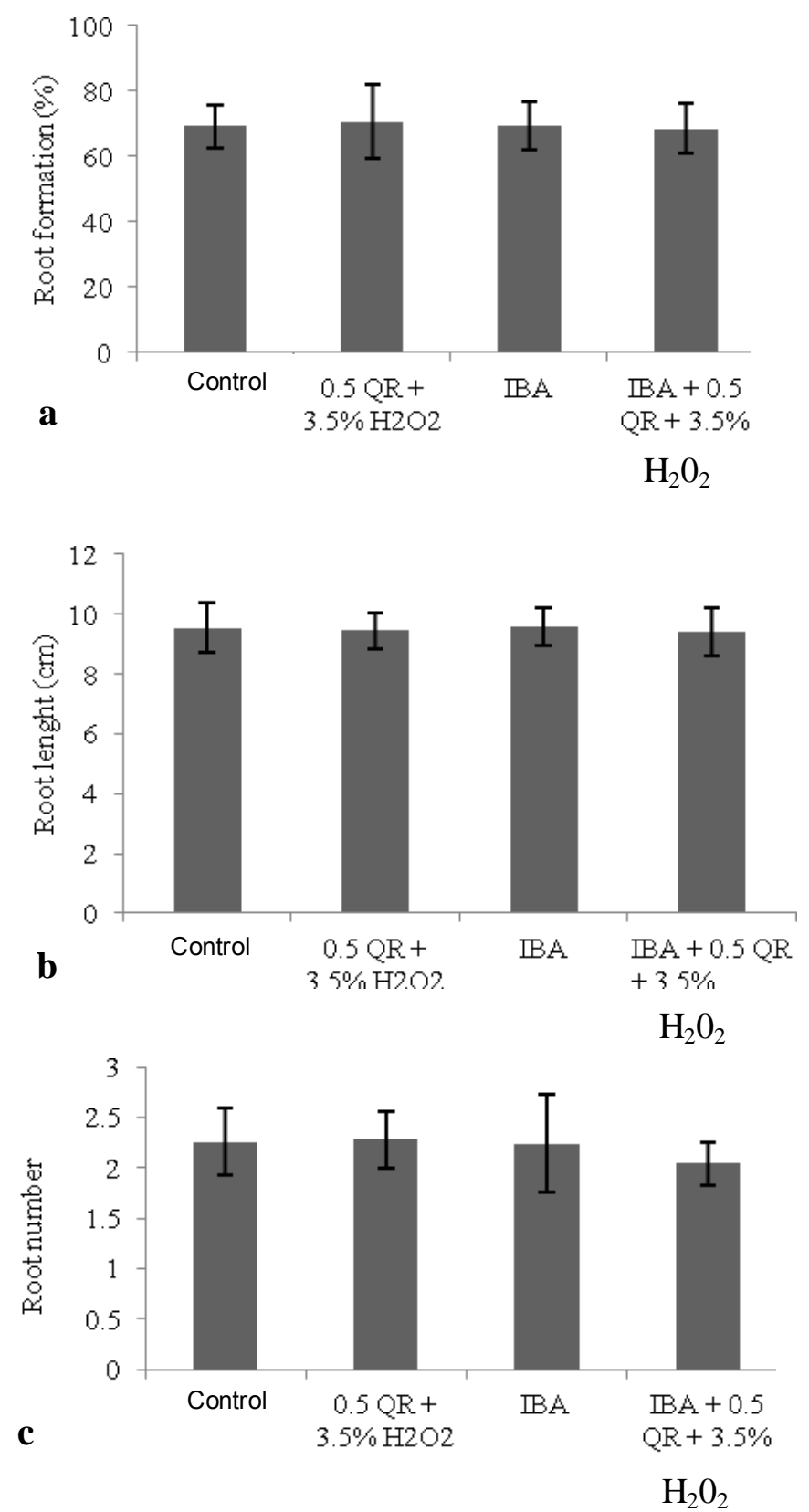

Figure 3. Effect of the addition of quercetin $\left(0.5 \mathrm{~g} \mathrm{~kg}^{-1}\right)$, associated with hydrogen peroxide $(3.5 \%)$, and indole butyric acid $\left(1.0 \mathrm{~g} \mathrm{~kg}^{-1}\right)$ on (a) root formation (\%), (b) root length $(\mathrm{cm})$ and (c) root number, measured at 90 days after planting of Eucalyptus grandis $x$ Eucalyptus urophylla cuttings

\section{Biochemical assessments}

In the present study, no effect on rooting and development of Eucalyptus seedlings were observed, thus changes found in the levels of polyamines and in their oxidation enzymes should be due to the effect of substances used during the treatments. No interaction effects (quercetin $x$ auxin $x$ hydrogen peroxide) were observed on the diamine putrescine (Put) in leaves, thus the effects of the factors were separated (Figures 4A and 4B). An increase in the content of putrescine in cuttings treated with quercetin, associated with $\mathrm{H}_{2} \mathrm{O}_{2}$, was observed (Figure 4B). Similar results were found for spermidine (Spd), either in the presence or absence of IBA, whereas decreased levels of spermine (Spm) were determined in the presence of a combination of IBA, hydrogen peroxide and quercetin (Table 4).

A reduction in the levels of putrescine, compared to 

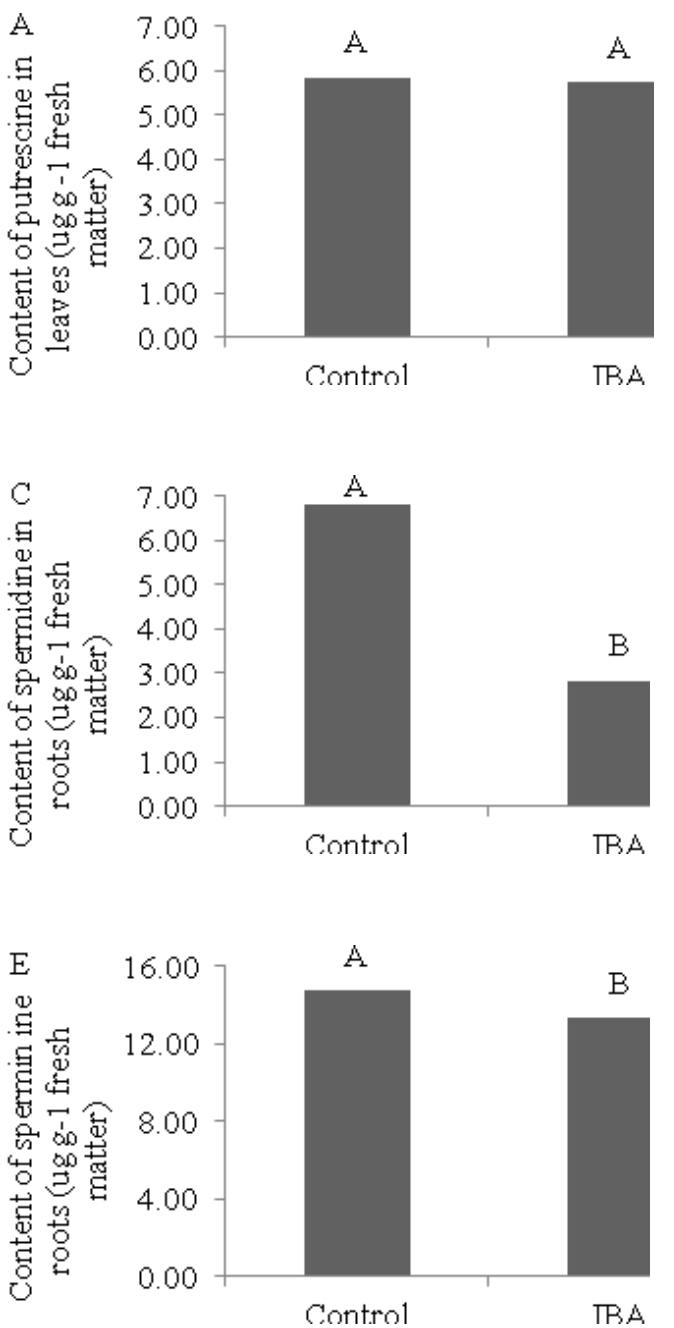
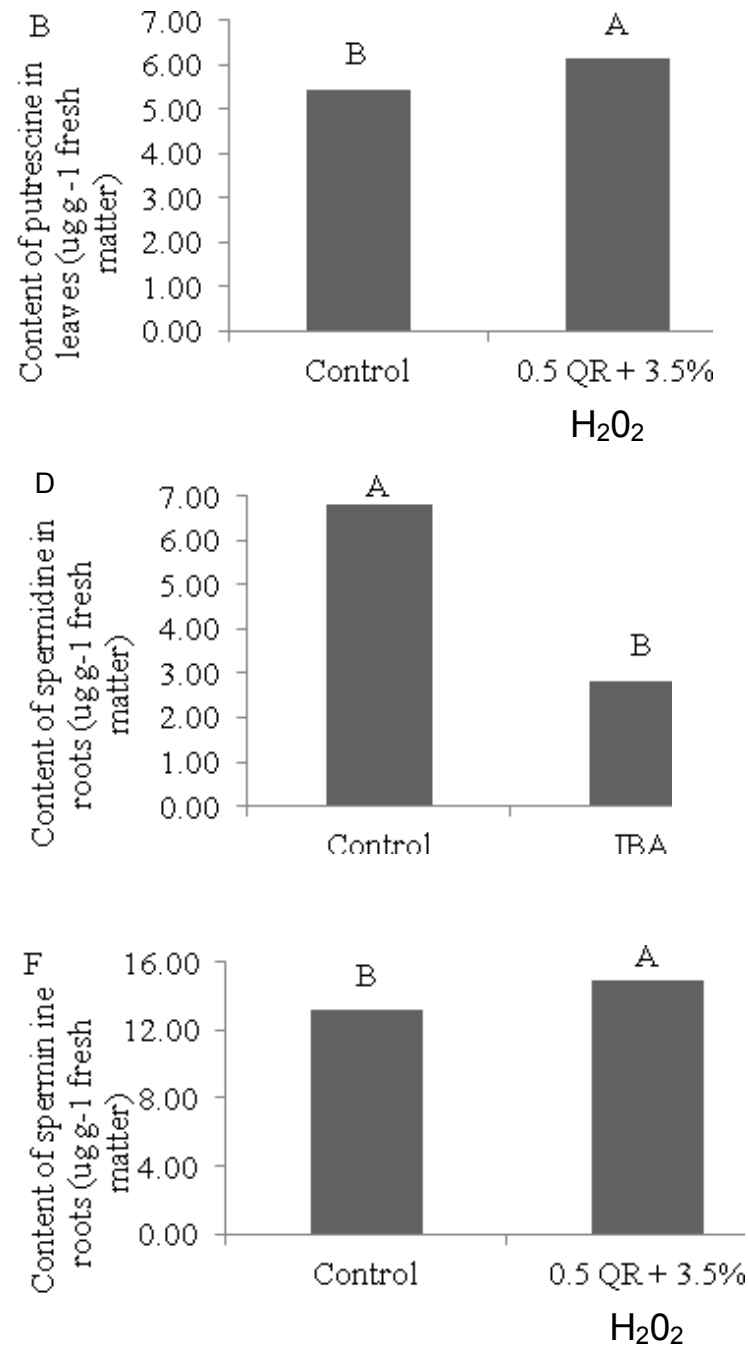

Figure 4. Content of putrescine in leaves $(A$ and $B)$, spermidine $(C$ and $D)$ and spermine $(E$ and $F)$ in roots of seedlings of Eucalyptus grandis $\mathrm{x}$ Eucalyptus urophylla treated with different combinations of hydrogen peroxide $(3.5 \%)$, quercetin $\left(0.5 \mathrm{~g} \mathrm{~kg}^{-1}\right)$ and indol butyric acid $\left(1.0 \mathrm{~g} \mathrm{~kg}^{-1}\right)$.

controls, was observed in roots for all treated samples (Table 4). The polyamines spermidine and spermine showed no interaction among used substances. The levels of both polyamines were reduced by the action of IBA (Figures 4C and 4D). The combination of hydrogen peroxide and quercetin did not alter the levels of spermidine (Figure 4D) and caused an increase of spermine content (Figure 4F). According to Su et al. (2006), the levels of agmatine (Agm), spermidine and spermine are positively related to root development, while the content of putrescine has a neutral or negative effect. Since all parameters related to growth and development were considered as satisfactory, it is possible that the clone used in the present report provided sufficient levels of polyamines, or that these plants are not responsive to treatments used due to insufficient levels of polyamines.

It has been reported that these substances are directly correlated with some specific phases of cell division
(Chattopadhyay et al., 2002). The lower concentration of polyamines in roots treated with quercetin, hydrogen peroxide and IBA (Table 4) than controls, may be related to a diminished capacity to synthesize putrescine, or alternatively, to the increased activity of polyamine oxidase (PAO), as documented (Table 5). This last result, evidencing a high catabolism of putrescine, was already described in young roots (Paschalidis and RoubelakisAngelakis, 2005).

Generally, in old tissues, a decrease in level of auxin is negatively correlated with the activity of amino oxidases (Cona et al., 2003). Thus, clones treated with auxin would present higher levels of polyamines and lower activities of PAOs. In the present study, no differences due to the addition of IBA on leaves were found. We observed a different effect in roots: i.e., the combined treatment with hydrogen peroxide, quercetin and auxin induced a decrease of the activity of polyamine oxidase. With a 
Table 5. Polyamine oxidase activity (expressed as $\Delta$ Abs $\min ^{-1} \mathrm{~g}^{-1}$ fresh weight) in leaves and roots of Eucalyptus grandis $\mathrm{x}$ Eucalyptus urophylla seedlings treated with different combinations of hydrogen peroxide $(3.5 \%)$, quercetin $\left(0.5 \mathrm{~g} \mathrm{~kg}^{-1}\right)$ and indole butyric acid $\left(1.0 \mathrm{~g} \mathrm{~kg}^{-1}\right)$.

\begin{tabular}{lccc}
\hline \multirow{2}{*}{ Parameter } & Quercetin + hydrogen peroxide & \multicolumn{2}{c}{ Polyamine oxidase activity } \\
\cline { 2 - 4 } & $\mathrm{H}_{2} \mathrm{O}_{2}(\%) ;$ Quercetin $\left(\mathrm{g} \mathrm{kg}^{-1}\right)$ & 0 & 1.0 \\
\hline & $0.0+0.0$ & $2.08 \pm 0.15$ & $2,37 \pm 0,42$ \\
Leaves & $3.5+0.5$ & $2.38 \pm 0.20$ & $2,38 \pm 0,40$ \\
& $\mathrm{CV}(\%)$ & & 13.79 \\
Roots & $0.0+0.0$ & $0.82 \pm 0.06 \mathrm{aA}$ & $0,91 \pm 0,13 \mathrm{aA}$ \\
& $3.5+0.5$ & $0.87 \pm 0.11 \mathrm{aA}$ & $0,71 \pm 0,03 \mathrm{bB}$ \\
\hline
\end{tabular}

*Lowercase letters compare means between treatments with indole butyric acid. Capital letters compare levels of hydrogen peroxide between each concentration of auxin. Means followed by the same letter are not statistically different by the Tukey test at $5 \%$ probability.

concomitant increase of putrescine content, which can also be observed from the value of polyamine ratio (Put/(Spd + Spm) $=0.29)($ Table 4).

No statistically significant differences were found in the activity of polyamine oxidase in leaves (Table 5). Differently, in roots of Eucalyptus seedlings, the activity of PAO was reduced upon treatment with quercetin alone and associated with IBA and hydrogen peroxide. Several reports showed the involvement of PAO on organism development and stress responses (Moschou et al., 2013).

Polyamine oxidases are responsible for the degradation of polyamines, which in turn influence different aspects of root development, such as an increased meristematic activity, leading to root elongation, lateral and adventitious root formation (Couee et al., 2004). However, this effect cannot be ascribed in the present study, since no alterations were observed with treatments. Generally, a low rate of polyamine catabolism occurs in young and growing leaves, as well as in apices (Paschalidis and Roubelakis-Angelakis, 2005). The lowest PAO activity was found in roots treated with hydrogen peroxide + IBA + quercetin, and it can be attributed to the presence of auxin, because low levels of this regulator have been associated with the expression of genes which induce the formation of PAO (Chen et al., 2001).

\section{Conclusion}

Cuttings of a clone (CL1) from E. grandis x Eucalyptus urophylla were treated with hydrogen peroxide in combination with quercetin or with indole butyric acid, and rooting and developmental parameters were evaluated. The clone was unresponsive to treatments used in relation to seedling height, diameter, survival, rooting percentage, root length and number of roots per cutting. Treatments induced a decrease of the levels of putre- scine and of the activity of PAO in roots. The absence of positive responses, the use of these substances as a treatment to improve seedling production is economically unviable. We suggest that in a future a research focusing on other bioactive ingredients.

\section{ACKNOWLEDGMENTS}

This research was supported by Fundação de Amparo a Pesquisa do Estado de São Paulo (FAPESP), Brazil (Grants 2012/14886-8, 2013/04678-1 and 2013/09954-7) and National Council for Scientific and Technological Development (CNPq) (Grant 306151/2012-0).

\section{REFERENCES}

Alfenas AC, Zauza EAV, Mafia RG, Assis TF (2004). Clonagem e doenças do eucalipto. UFV, Viçosa, Brazil.

Angelini R, Cona A, Federico R, Fincato P, Tavladoraki P, Tisi A (2010). Plant amine oxidases "on the move": an update. Plant Physiol. Biochem. 48:560-564

Bandurski RS, Cohen JD, Slovin JP, Reinecke, DM (1995). Hormone biosynthesis and metabolism. Auxin biosynthesis and metabolism. In: Davies PJ, editor. Plant Hormones - Physiology, Biochemistry and Molecular Biology. Dordrecht, Netherlands, 2:39-65.

Brondani GE, Baccarin FJB, Ondas HWDW, Stape JL, Gonçalves AN, Almeida MD (2012). Low temperature, IBA concentrations and optimal time for adventitious rooting of Eucalyptus benthamii minicuttings. J. Forest. Res. 23:583-592.

Chattopadhyay MK, Tabor CW, Tabor H (2002). Absolute requirement of spermidine for growth and cell cycle progression of fission yeast (Schizosaccharomyces pombe). Proc. Natl. Acad. Sci. 99:1033010334.

Chen J, Shimomura S, Sitbon F, Sandberg G, Jones AM (2001). The role of auxin-binding protein 1 in the expansion of tobacco leaf cells. Plant J. 28: 607-617.

Cona A, Cenci F, Cervelli M, Federico R, Mariottini P, Moreno S, Angelin R (2003). Polyamine oxidase, a hydrogen peroxide producing enzyme, is up-regulated by light and down-regulated by auxin in the outer tissues of the maize mesocotyl. Plant Physiol. 131:803-813.

Corrêa LDR, Fett-Neto AG (2004). Effects of temperature on adventitious root development in microcuttings of Eucalyptus saligna Smith 
and Eucalyptus globulus Labill. J. Therm. Biol. 29:315-324.

Couée I, Hummel I, Sulmon C, Gouesbet G, Amrani AE (2004). Involvement of polyamines in root development. Plant Cell Tiss. Org. 76:110.

Dunand C, Crevecoeur M, Penel C (2007). Distribution of superoxide and hydrogen peroxide in Arabidopsis root and their influence on root development: possible interaction with peroxidases. New Phytol. 174:332-341.

Flores HE, Galston AW (1982). Analysis of polyamines in higher plants by high performance liquid cromatography. Plant Physiol. 69:701706.

Franklin G, Dias ACP (2011). Chlorogenic acid participates in the regulation of shoot, root and root hair development in Hypericum perforatum. Plant Physiol. Biochem. 49:835-842.

Groppa MD, Benavides MP (2008). Polyamines and abiotic stress: recent advances. Amino Acids. 34:35-45.

Hartmann HT, Kester DE, Davies FT, Geneve RL (2002). Plant propagation: principles and practices. Prentice-Hall, New Jersey, USA.

Kusano T, Berberich T, Tateda C, Takahashi Y (2008). Polyamines: essential factors for growth and survival. Planta, 228:367-381.

Li SW, Xue LG, Xu SJ, Feng HY, An LZ (2009). Hydrogen peroxide acts as a signal molecule in the adventitious root formation of mung bean seedlings. Environ. Exp. Bot. 65: 63-71.

Lima, GPP, Rocha AS, Takaki M, Ramos PRR, Ono EO (2008). Comparison of polyamine, phenol and flavonoid contents in plants grown under conventional and organic methods. Int. J. Food Sci. Tech. 43:1838-1843.

Mendes AFS, Cidade LC, Otoni WC, Soares-Filho WS, Costa MGC (2011). Role of auxins, polyamines and ethylene in root formation and growth in sweet orange. Biol. Plant. 55: 375-378.

Moschou PN, Roubelakis-Angelakis KA (2013). Polyamines and programmed cell death. J. Exp. Bot. 1-12.

Nag S, Saha K, Choudhuri MA (2001). Role of auxin and polyamines in adventitious root formation in relation to changes in compounds involved in rooting. J. Plant Growth Regul. 20:182-194.

Pandey D, Pathak RK (1981). Effect of rootstocks, IBA and phenolic compounds on the rooting of apple cuttings. Progr. Hort. 13:105-110.

Paschalidis KA, Roubelakis-Angelakis KA (2005). Sites and regulation of polyamine catabolism in the tobacco plant. Correlations with cell division/expansion, cell cycle progression and vascular development. Plant Physiol. 138:2174-2184.

Peer WA, Murphy AS (2007). Flavonoids and auxin transport: modulators or regulators? Trends Plant Sci., 12:556-563.

Pio R, Ramos JD, Chalfun NNJ, Coelho JHC, Gontijo TCA, Carrijo E (2003). Rooting of fig tree apical cuttings using sucrose and iba by quick immersion. Curr. Agr. Sci. Tech. 9:357-360.
Sebastiani L, Tognetti R, Paolo P, Vitagliano C (2002). Hydrogen peroxide and indole-3-butyric acid effects on root induction and development in cuttings of Olea europaea L. (cv . Frantoio and Gentile di Larino ). Adv. Hort. Sci. 16:7-12.

Sebastiani L, Tognetti R (2004). Growing season and hydrogen peroxide effects on root induction and development in Olea europaea L. (cvs 'Frantoio and 'Gentile di Larino') cuttings. Sci. Hortic. 100:7582.

Stevanato R, Mondovi B, Sabatini S, Rigo A (1990). Spectophotometric assay for total polyamines by immobilizes amine oxidases. Anal. Chim. Acta, 237:391-397.

Su G, Zhang W, Liu Y (2006). Involvement of hydrogen peroxide generated by polyamine oxidative degradation in the development of lateral roots in soybean. J. Integr. Plant Biol. 48:426-432.

Tarragó J, Sansberroa P, Filip R, López P, González A, Lunaa C, Mroginskia $L$ (2005). Effect of leaf retention and flavonoids on rooting of Ilex paraguariensis cuttings. Sci. Hortic. 103:479-488.

Vignolo GK, Fischeri DLO, Araujo VF, Kunde RJ, Antunes LEC (2012). Rooting of hardwood cuttings of three blueberry cultivars with different concentrations of IBA. Cienc. Rural, 42:795-800.

Xavier A, Wendling I, Silva RL (2009). Silvicultura clonal: princípios e técnicas. UFV, Viçosa, Brazil. 